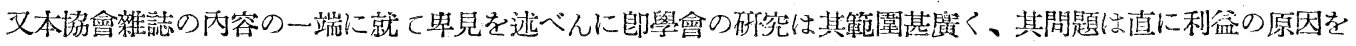
なさずとも敢て問ふ所でないから、対何なる種類の問題を擇ぶも何の支障なく且近特は何々資金といふるのを 基礎とし學界の䂰究費に充つるもの甚多く、加ふるに大學の數を增したる䉆め一層呼究者も䓕多くなれるに反 し、實業界の問題は稀には問題外のものもあれど、多くは常に經濟上のものに限定され加ふるに其研究費など は叙上の吝き資金を得ず又砄究室さえ所有せざる有樣にあり、而して其砄究したる問題に就て見るに學界に於 ては研究の價值なし否斯榚なる研究は其砄究所又學校の權威に關するが故に發表を見合はせ沒收するといふが

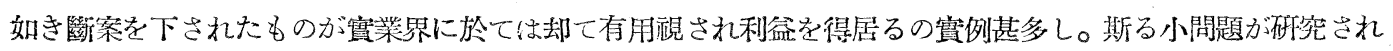

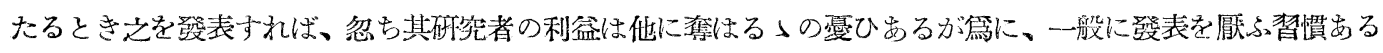
は勿諭の事なり、是れ苴業界の研究が雜誌上に現はる〉事の尠なき一因をなせるものである。

次に本會の名をして世界的ならしむる運動の是非に就きて一言せんに小子は之に對して決して不賛成を唱ふ る譯ではないが、さりとて世界各國沦名を知らしむることが、本會の第一の目的ではない郎ち會員が主であり、 世界的の事は從である。未だ主の方に光分ならずして從のうにうを畵すは主客轉倒である。今暫く主に重きを 置くの要ありと信ずるものである。

妶に於てか子の日はんと欲するものは他にあらず、郎ち此際等業學會と筧業協會の兩者に分離し以て各獨立

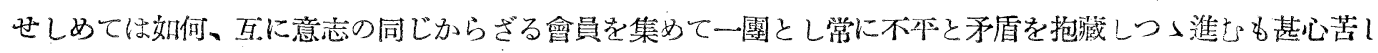
いのみならず、其發達をして却て遲々たらしむる一因となるやも知れざればなり。

年頭に當り本會の本質を究め、本會行動の目標を見定めんとしたり、大方諸君の䘖批判を乞ふ。

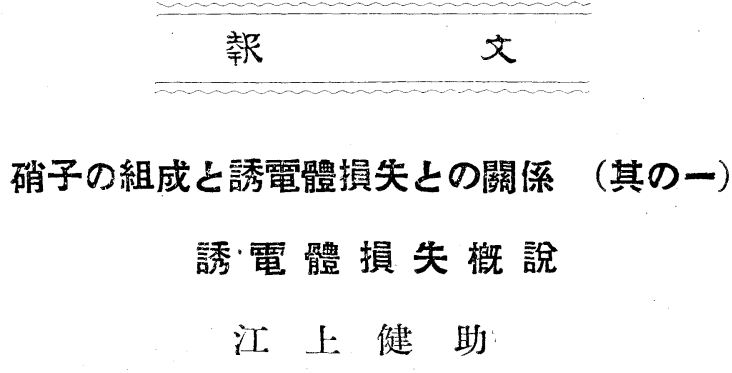

The Relationship between Chemical Composition and the

Dielectric Loss of Glass (I)

A Résumá on Power Loss of Dielectrics

Kensuke Egami.

緒言

從來确子は電氣絕緣材料の一として照明、通信、其他の電氯的方面に其の用途は可なり大なるものであるが 輓近各種電氯工業の發奎就中、短波長無線通信の蕉步は更に優秀なる電氯絕緣材料需用つ聲を高妙子の吝き も從來のものを以てしては到底其の要求を滿足せしめ得ない迄に至つてるる。從て近時この方面に於汁る咑究 も行はれその所萑として從來のものに比し更に良好なる性質を有寸る三、三の硝子か既に市場に現れてるる。 筆者も傾日來電氯的に優秀なる确子を得る目的の下に硝子の組成と交流電場に於汁る其の誘電澧損失との關倸 
に付き砸究を行ひつ〉あり其結果組成に適當なるものを得る時は從來のものに比し誘電體損失の極めて少なき 優秀なる硝子を得る事必しも難事に非ざる事を知り得たのである。本報交は其等の結果について記述する目的 で等をとつたものであるがそれに先つて硝子等の如きもの電氣縃緣物として使用するに當つて其の電氣的性 質上最も重要なる問題の一となる艾流電場に於ける誘電體損失及び其れを specify する誘電體 力率に就いて 述べる事も又從勞ではないと考へるので其等に關し以下簢單なる記述を試みたのである。笔者元より電氣專攻 の者ではなく從つてこれ等誘電體に關する詳細なる電氣的理論乃至事項に就いては可諭知る由もない、故に以 下記する所も硝子研究者としてのこの方面に於ける單なる賞識程度の極めて幼稚なるものに過ぎないのであり 或は又記述の中には篫者の理解に誤りがあるかも計り難い。これ等の點に就いては切に諸賢の御寬怒を御䫌い すると同時に御㸚示を賜るを得ば笔者望外の喜びである。

\section{I. 誘電體}

(1) 完全誘電體

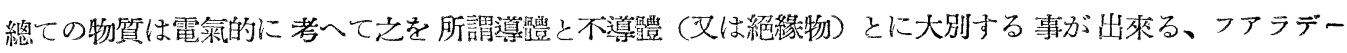

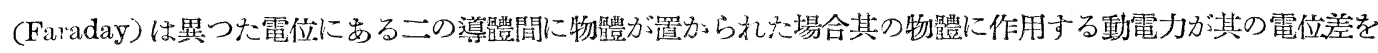
消失せしめて或る一定の電位に迄持來らしめるが如き電氣の移動を行はんとするに對して直にこれを生ぜしめ ざるが如き絕緣力を有するすべての物體を誘電艠 (Dielectrics) と稱してるる。從てすべての絕緣物は誘電體 と考へる事が出來る。

今導體よりなる A,B 2 個の板面間に誘電體を摤しだものに就いて考へて見る。これは全體として一つの蓄 電器を形成してるる。この畝電器の導圆板 $A, B$ の何れか一つを接地し他の導體板に $Q$ なる電荷を與へ其の 電位がVになつたとする、然る時は $V, Q$ 間には次の關係が成立する。

$$
V=Q / C
$$

この $C$ は一つの蓄電器に就いては定數であつてこれを蓄電器の容量 (capacity) と稗する。A 亿於ける十

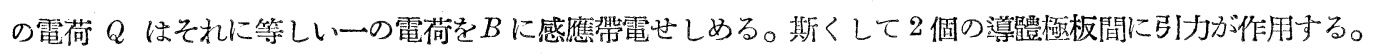

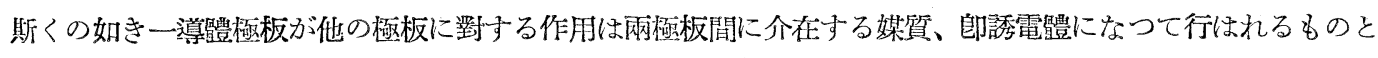
考へられ斯くの如き狀態にある誘電體は電氯的成極 (electric polarization) の狀態にあると稱してるる。 アラデーは蓄電器の容量は極板の大さ並に兩極板間の距㒕によるのみならず其の間にある誘電體の種類にも訨 るものである事を發見し或る誘電鸦を媒質として作られた蓄電器の容量 $\mathrm{C}$ のこれと同大同形にして空氣を誘 電體とする蓄電器の容量 $C_{0}$ に對する比即 $C / C_{0}=\varepsilon$ を其の誘電體の誘電率 (Specific inductive capacity) と 定義してるる。從つて

$$
Q=C V=\varepsilon C_{0} V
$$

若し理想的な誘電體であれば上述の樣にして Q なる電荷が蓄電器に與へられる時は其處に本衡狀態が成立 し更に其の上の電氯の移動は起らない。而して誘電體內には電位傾度が存在し又 $V$ 作用をうけて成極が成立 す。マックスウェル (Maxwell) はこの成極なるものはVなる電位差によつて生起された電氣變位なる現象 (electric displacement, 同氏によつて斯く名づけられた)に一致すると考へた。郎同氏は誘電體を通つて所謂 電氣の流動は行はれないが或量の變位が行はれ得る。而して其の變位は其れを生起せしめた電位差の方向にし かも其れに比例するものであると考へたのである。この變位は誘電澧の單位面樍を通つて變位する電氣量によ

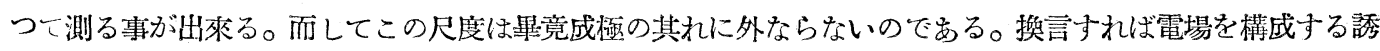




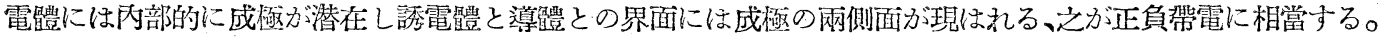

更に電場內の一點に於汁る成極の程度は先其の點に於ける電場の强さ $F$ に比例し又一方電場の誘電率 $\varepsilon$ に 此例する。故に成㮀は $\varepsilon F$ にて秤量する事が出來る。マックスウエルはこの成極を特に電氣變位と構しDで 表した。郎

$$
D=\varepsilon \bar{F}
$$

これを電稀單位。で表せば

$$
D=\varepsilon F / 4 \pi v^{2} \quad v \cdots \text { 光の速度 }
$$

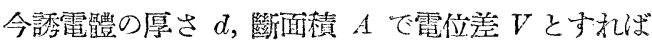

$$
D=\varepsilon V / 4 \pi v^{2} d
$$

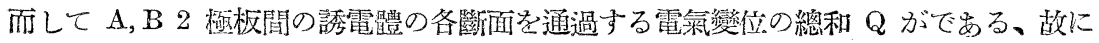

$$
Q=D \times A=\varepsilon V A / 4 \pi v^{2} d
$$

で表はされる。

(2) 一般誘電體

現在一般に使用せられてるる固體或は液䣓の誘電體で完全なる誘電體と考へられるものは存在しない。これ らの誘電體は何れもこれに電位差を與へる時は㨁に電氣の移動を生じて電氣變位なる現象が生起されると同時 に僅ながらも繇電流を生ずる。聯面樍 $A$ 厚さ $d$ なる誘電體の一片に就いて考へるにVなる電壓が其の兩端面

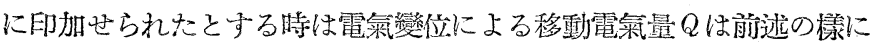

$$
Q=D \times A=\varepsilon V A / 4 \pi v^{2} d
$$

これと同時に導電流 $i_{c}$ が流れる。その量は

$$
i_{c}=\frac{A \boldsymbol{\sigma} V}{d} \quad \sigma \cdots \cdots \text { 詮電體の電盙率度 }
$$

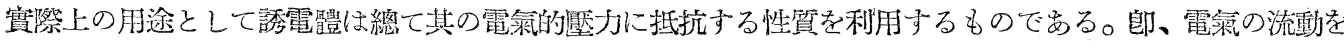
生ずる事なく大なる電㙠の作用に堪へるものである。然し乍らこの場合これが完全なる誘電體に非らざる限り 僅少ながらも電流は流れる事は前述の通りである。この導電流は一般に漏洩電流と䅉せられこれが小さい程絕

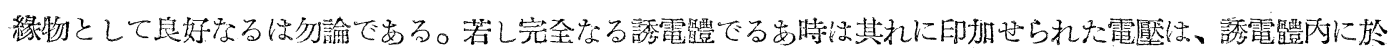
て電氣變位を生起するの久でこの電壓が除かるれば變位も消失する、從て變位が起つた時は誘電體內で或る量

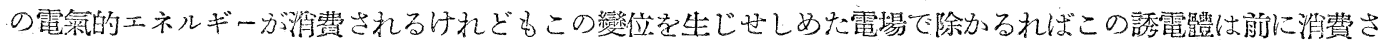

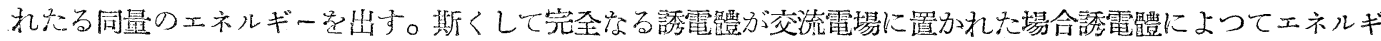
一は艾互に韵藏及放出が行はれ其處にはエネルギーの損失は生じない事になる。然し實際に用ひられる誇電體

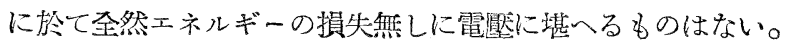

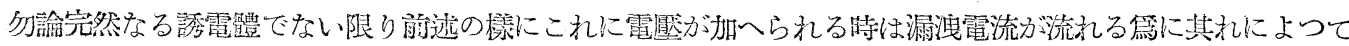
エネルギーの損笑は賞然考へられるが、交流電場に置かれなる場合のエネルギーの損失は前記の漏洩電流から 豫期される量よりも遥に大で出る。この惠演は斯くの如き交流電場に於ける誘電體の電力損失については更に 他の原因がこ机に加はる事掌预想せしむるものである。

(3) 一般誘電體の異茯現象

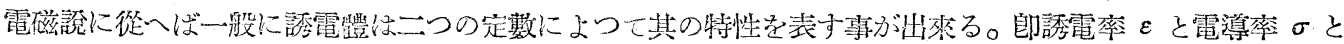

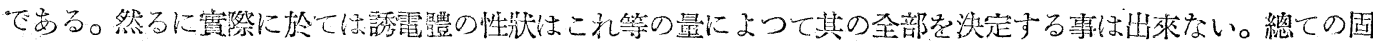




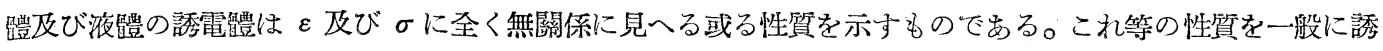
電體の暴常性といつてるる。苳流電場に於ける電力損失は實際上最も重要なる異常性の一つでむる。又誘電體 に於ける残留現象、及び四收現象に重要なる異常性の現れである。しかるこれ等の現象と交流電場に於ける電 力損失との閒には密接なる關係が存在するもので寧この吸收現象は更に根本的なる現象と見る事が出來る。

完全なる誘電體からなる本行板蓄電器に於てこれに一定なる電位差 $V$ 與へる。然る時は謤電體は電氣變位 尼生起し蓄電器は充電され $Q=C V$ なる電氣量が蓄電される。斯の如くして蓄電器を充電する電流を充電電流 と稱する。この電流は瞬時にして零に澾して止む。若し誘電體が或る電導率を有してるるならばこの充電電流 の外に霓に一定の導電流が流れる。而して充電電流が零になつてもこの導電流は電壓が保たれてるる間は連續 して流れる。逆に蓄電器の放電を行ふ時は放電電流が流れるがこれは直に零になる。而して導電流は電壓の除 去と共に止む。

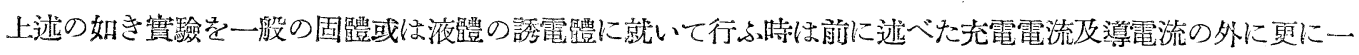
つの電流が流れる。この電流は漸減電流で時間と共に減少するがしかも數時間乃至數日間連續する事も稀では ない。斯くの如き漸減電流を吸收電流（absorption curreut）と稱する。換言すれば一般誘電體に直流電厣を 加へると電壓印加の睃間から漸減電流が或る時間流れる。而して最後には一定值に達する。この電流に於て電

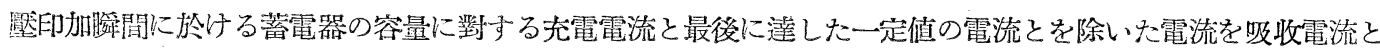

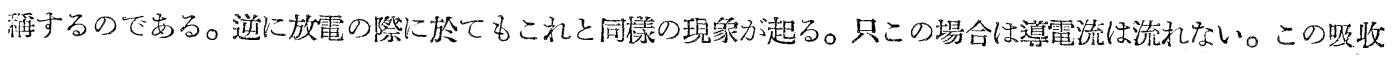
電流によつて運ばれる電荷は売電の瑒合誘電蹬によつて吸收せられ放電の瑒合放出されるものでこの現象を吸 收現象そ稱してるる。叉これ等の誘電體に直流電壓を加へたる後電路を切つて電厴印加を停止すると其の雨端 に一般に正印加の端が正極に負印加の端が負極になつた電位が殘留する。こっに殘留する電荷は前述の場合に

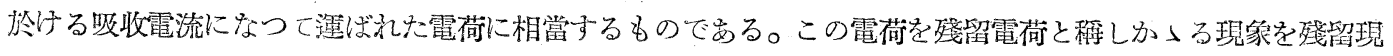
象と䅜する。

上述の対き吸收現象を示す一般誘電體を卒流電場に持來す時は吸收現象が主なる原因をなして誘電福內に於 て或る量の電力損失を生ずるに至るものである。これ等直流電場に於ける吸收現象及び其れより推諭せられる

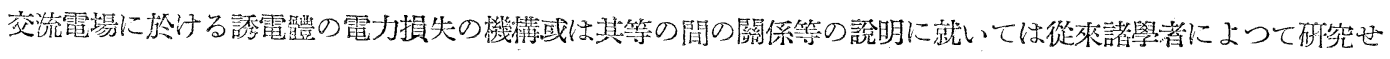

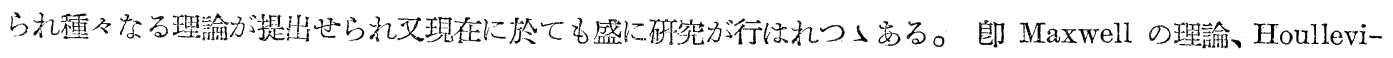
gue 及び Pellatによつて提唱せられた Dielectric Hysterisis 說、Schweidler, Wagner 等の理諭、Thoru一 ton より提出せられそ Inter-attraction 譛、Günther-Schurze による Ionic 說、或は又 Deby による Di-

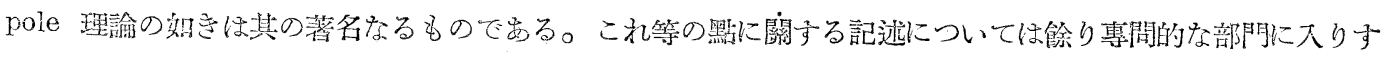
ぎるのでこっでは省略する。

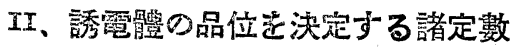

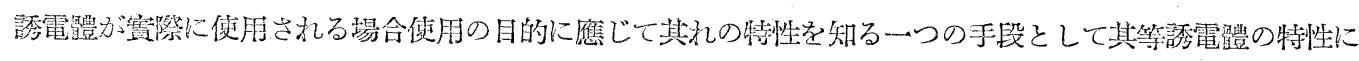
關する定数老決走する。一般に誘電體の使用に際して常に間題となるものは次の諸䁫である。

(1) 㮇電交

誘電砻に就いては前に述べたのでこっでは省略する。

(2) 絶緣提抗 
漏洩電流を決定するに必要なもので絕緣抵抗を表す定數としては娟積固有抵抗 (volume resistivity) であ る。即誘電體の 1 糎立方體の兩對面間の電氣抵抗である。然し乍ら一般に固體の誘電觶の場合は漏洩電流は二 つの部分から成る。一つは其の物體內部を流れる電流で、他の一つは其の表面を流れる電流である。前者は全 く物其れ自身の性質であるが後者は物裋の表面に附着せる水分或は他の物質の薄層を通つて流れるもので元よ り誘電體自身の性質によるが、更に外界の影響を受ける事も大でこの表面の漏洩電流を決定する定數を特に表 面固有抵抗と稱する。

(3) 絕線破壞

絕綠物に印加した電㾏を次第に增大すると或る值に達した時其の絕緣物を通つて或は其の表面に沿ふて絕綠 力が破壞される。これを絕緣破壞と謂ひ其の時の電壓を絕緣耐力或は耐電壓と稱する。絕緣物の表面で電弧が 續いて沿面火花放電が起り絕緣が破壤される電烈を表面弧絡電壓或は單に弧絡電壓と謂ひこれに對して絕緣物

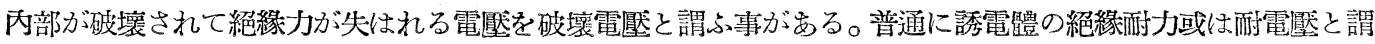
ふ時にはこの意味の事が多い。表面弧絡電壓は物質の種類による事は勿論であるが其の外に電極の形、距離及 び相對的位置、電源の種類、電壓印加の時間、表面の狀態、外氣の狀態等の影響により羑異を生ずる、破壤電 黳も亦物質の種類による外に電極の形、距離、電源の種類、電㙠印加時閒等の影響により差異を生ずる。

(4) 誘電體損失

前にも述べた樣に誘電澧を交流電場に置く時は常に或る量の電力が誘電體內で熱となつて消費せられ誘電體 の溫度を上昇せしめる。かつる電力損失を一般に誘電體損失と謂ふ。この誘電體損失は勿論物質自身の性質に よるものであるが其他に種々外的な諸條件の影響を受ける事が大なるものである。本稿はこれに就いて述べる のが其の主なる目的であるからこれを決定する數值に就いては次章に䋛述する。

\section{III、誘電體損失}

誘電體に交番電㗨を印加した場合誘電體內で消費される電力は種々なる方法で specify されてるる。以下述 べるのも其の一である。一般に導㣶と譚電體とが其に電氣的に使用される場合其は一つ湆電器と看做す事が出 來る。從つて誘電體損失の問題を取拆ふ場合はこの誘電體を持つ蓄電器に就いて考へればよい。

今蓄電器の久を有する電路に於てこれに交番電壓を印加ずる時は其の電路に一つの電流か流れる。其の際用 ひられた誘電體が完全なものであれば電力の損失は生じないのである。この場合の印加電壓が正弧弦型のもの である時は電厴 $v は$

$$
\begin{aligned}
& v=V_{0} \sin \omega t \\
& V_{0} \ldots \ldots \ldots \text { 電壓の最大值 } \\
& \omega=2 \pi f \cdots \text { 電氣的角速度、 } f \text { は周波數 } \\
& t \cdots \cdots \cdots \text { 時間 }
\end{aligned}
$$

で表される。誘電體の容量を $C$ とすれば蓄電量 $q$ は

$$
q=C_{v}=C V_{0} \sin \omega t=Q_{0} \sin \omega t \quad Q_{0}=C V_{0} \cdot g \text { の最大值 }
$$

流れる電流 $i$ は

$$
i=d q / d t=V_{0} C \omega \sin \left(\omega t+90^{\circ}\right)=I_{0} \sin \left(\omega t+90^{\circ}\right) \quad I_{0}=V_{0} C \omega \cdots i \text { の最大値 }
$$

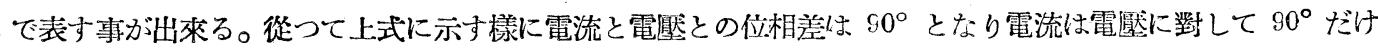
進む事になる。 
然るに一般に使用される固體（或は液體）の䛪電體に於ては前にも述べた通り或量の電力が常に誘電斟內て

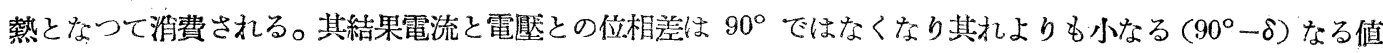

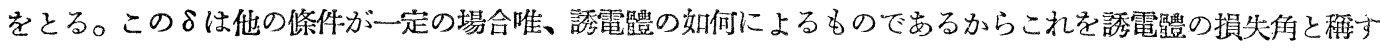
る。この場合電流及び電㙠の實效值を各 $I$ 及び $V$ とすれば電力損失量 $W$ は

$W=I V \sin \delta$

で表される。この $\sin \delta$ を誘電體の力率 (power factor) と䅺する。郎この值が小さい程誘電體として良いと いふ事になる。

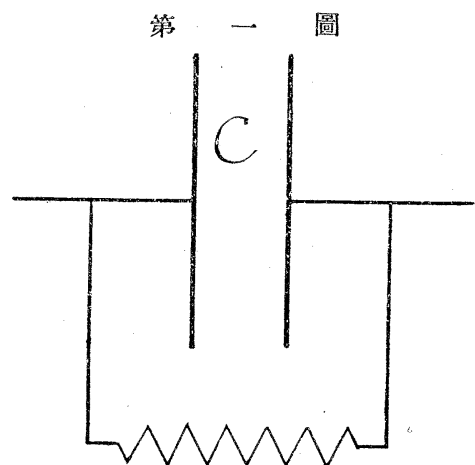

$R$

$\sec \delta=\sqrt{1+\tan ^{2} \delta}$

$\operatorname{cosec} \delta=\sqrt{1+\cot ^{2} \delta}$
斯くの如き損失を有する蓄電器は其の損失の起る傎の機棈は別問

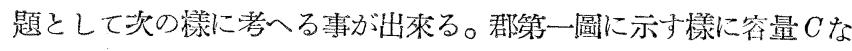
る完全なる誘電體を有する滰電器とこれに並列に非常に大なる抵抗 $R$ とを組合せたもので電打損失はこの抵抗によつて生じたものと考 へる。

斯くの如き電路に於て $v=V_{0} \sin \omega t$ なる電壓が印新される時は 電流 $i$ は次の樣になる。

$$
\begin{aligned}
i & =v / R+d q / d t=v / R+C d v / d t \\
& =V_{0}(1 / R \cdot \sin \omega t+C \omega \cos \omega t)
\end{aligned}
$$

$(1 / R) / C_{\omega}=\tan \delta$ で表す時は

$$
\therefore \cos \delta=\omega C / \sqrt{\omega^{2} C^{2}+1 / R^{2}}
$$$$
\therefore \sin \delta=(1 / R) / \sqrt{\omega^{2} C^{2}+1 / R^{2}}
$$

$\therefore \quad i=V_{0} \sqrt{a^{2} C^{2}+1 / R^{2}}(\sin \omega t \sin \delta+\cos \omega t \cos \delta)$

$=V_{0} \sqrt{\omega^{2} C^{2}+1 / R^{2}} \cos (\omega t-\delta)$

$=V_{0} \sqrt{\omega^{2} C^{2}+1 / R^{2}} \sin \left(\omega t+90^{\circ}-\delta\right)$

$=I_{0} \sin \left(\omega t+90^{\circ}-\delta\right)$

但. L,$V_{0} \sqrt{\omega^{2} C^{2}+1 / R^{2}}=I_{0}$

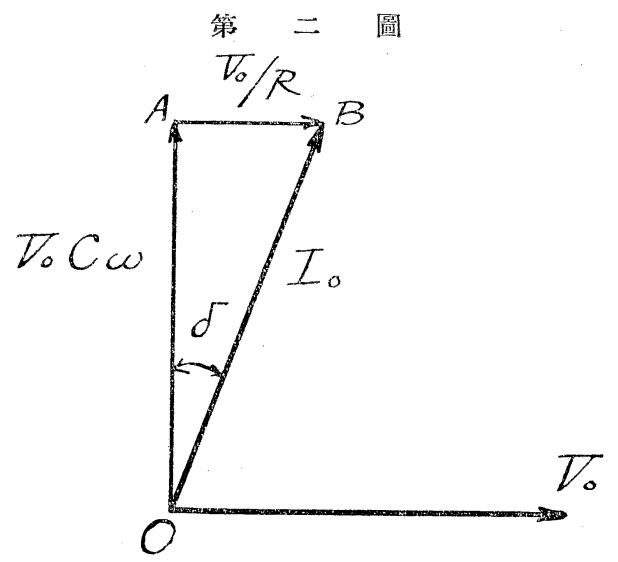

斯くして電流は電壓に對し $\left(90^{\circ}-\delta\right)$ だけ進む寒になる この場合の電流と電壓とのグェクトル圖は第二圖 の㨾に なる。

第二圖の樣に $V_{0}$ なる電壓力゙印加される時は流れる電流 $I_{0}$ はこれ贵二つの成分に分けて考へる事が出來る。郎電悘 $V_{0}$ K淔角の方向の成分 $0 A$ と $V_{0}$ に平行なる成分 $A B$ の 三つで前者は $C$ なる容量の韵電器に於ける電流であり後 者は並列にある抵抗 $R$ による電流である。 $V_{0}$ 老電壓の最 大値とすれば

$$
\begin{aligned}
& O A=V_{0} C \omega \\
& A B=V_{0} / R
\end{aligned}
$$


而して管祭の電流 $O B$ 郎 $I_{0}$ はこの雨者のグェクトル和で表される。

この場合蓄電器の䆟量 $C$ は

$$
C=I_{0} \cos \delta / V_{0} \nsim
$$

で表される。又

$$
\tan \delta=(1 / R) / C \omega=G / C \omega \quad[1 / R=G]
$$

である。の值が非常に小さい時は

$$
\sin \delta \div \tan \delta
$$

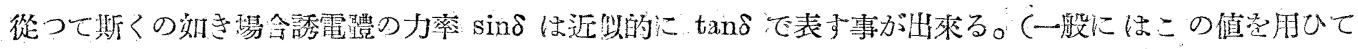
るる。)

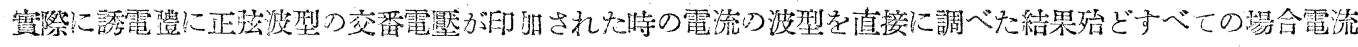

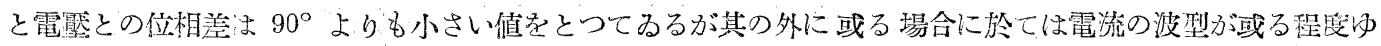

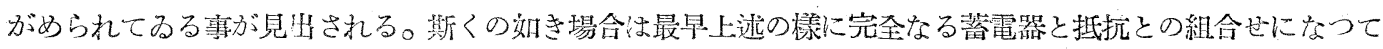

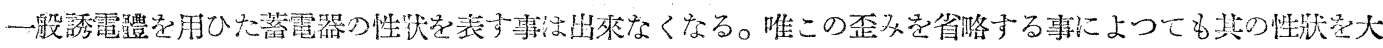
體說明し得られる。從つて今はこの歪はないるのとして說明する。

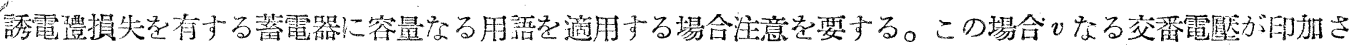
れた時電流 $i$ 及び蓄電量 $q$ は前述の樣に

$$
\begin{aligned}
& v=V_{0} \sin \omega t \\
& i=I_{0} \cos (\omega t-\delta) \\
& q=I_{0} / \omega \sin (\omega t-\delta)=Q_{0} \sin (\omega t-\delta)
\end{aligned}
$$

容量は一般に $q / v$ で表去れる。而して芫全なる誘電蹬に於ては

$$
q / v=\frac{Q_{0} \sin \omega t}{V_{0} \sin \omega t}=\frac{Q_{0}}{V_{0}}
$$

であるから勿諭定數である。然し乍ら一般の誘電體に於てはこの值は定數ではない。郎

$$
q / v=\frac{Q_{0} \sin (\omega t-\delta)}{V_{0} \sin \omega t}
$$

從つて一周期つ间に於て $q / v$ は種々なる值をとり得る。斯くの吝き場合容量として吝何なる値をとるかに就

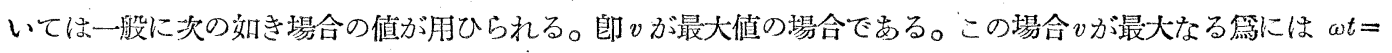
ル/2 でなければならない。從つて

$$
\begin{aligned}
q^{\prime} v & =\left[Q_{0} \sin (\pi / 2-\delta)\right] / V_{0} \\
& =\left(Q_{0} \cos \delta\right) / V_{0} \\
& =\left(I_{0} \cos \delta\right) / V_{0} \omega=C
\end{aligned}
$$

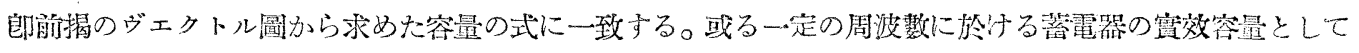
は一船にこの值をとる。この值は僅ではあるが周波數によつて變化する。從つて其の值から計算される所謂漂

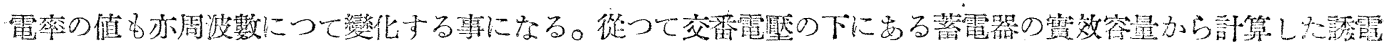
率の值を隻其の條化に於汸る permittivity なる語で表してるる。

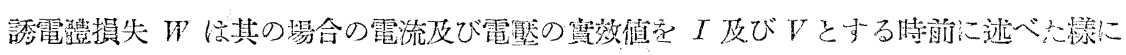




$$
W=I V \sin \delta
$$

又蓄電器の蒀效容量は電流、電赜共に實效値をとる時は

$$
C=I \cos \delta / V \omega
$$

故に

$$
W=V^{2} \omega C \tan \delta
$$

となる。 permittivity をもとすれば前述の樣に

$$
\boldsymbol{\epsilon}=C / C_{0}
$$

從こて

$$
W=V^{2} \omega \epsilon C_{0} \tan \delta
$$

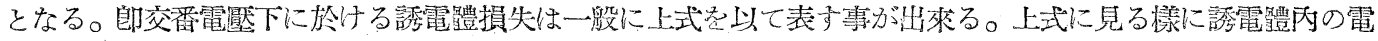

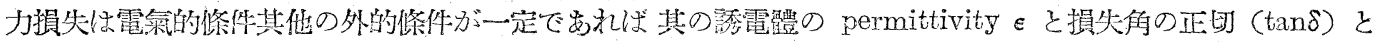

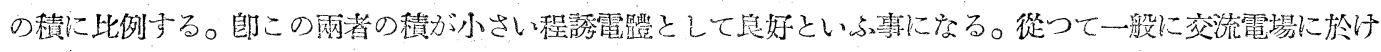

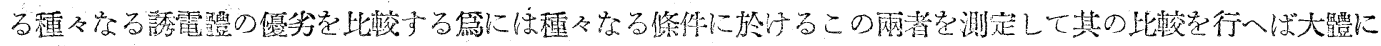

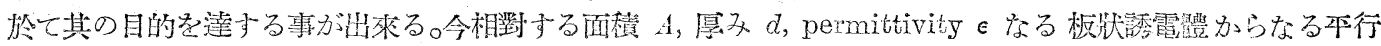
板蓄電器に就いて其の蒷效容量を賞用單位。゙表ぜ゙

$$
C=A \epsilon / 9 \times 10^{\prime \prime} \times 4 \pi d \text { フアラッド }
$$

從つて誘電體損失 $W$ は

$$
\begin{aligned}
& W=V^{2} \omega C \tan \delta \quad \text { ワット } \\
& =V^{2} A \epsilon \omega \tan \delta / 9 \times 10^{\prime \prime} \times 4 \pi d \quad \text { ワット }
\end{aligned}
$$

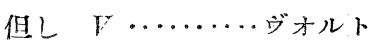

$$
\begin{aligned}
& \omega=2 \pi f \\
& f \ldots . . . \text { 将ィル秒 } \\
& \text { C ……ファラッド } \\
& A, d, \cdots \text { C. G. S. 單位 }
\end{aligned}
$$

\section{VI. 誘電體損失に對する外的諸條件の影響}

交流電場に於ける誘電䯠の電力損失に就いては種々なる外的條件の影響が考へられる。其等の考慮さる可き

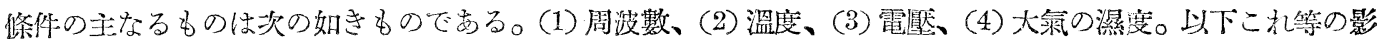
響に就いて簡單に述べて見る。

(1) 周渡僌の變化による影響

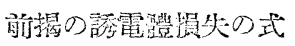

$$
\begin{aligned}
W & =V^{2} \omega C \tan \delta \\
& =V^{2} 2 \pi f C \tan \delta
\end{aligned}
$$

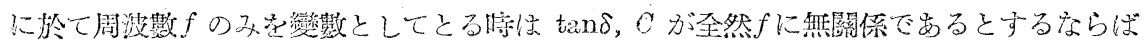

$$
W=k f
$$

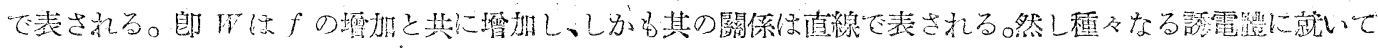

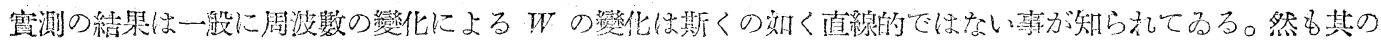

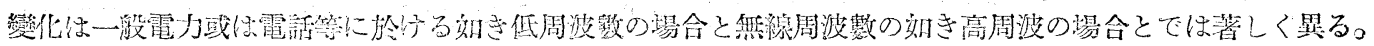


上記の如く $W$ が $f$ の次式で表されると見て差しつがないのはきはめて短い範圍の間のみである。一般 には低周波數の場合は

$$
W=k f^{m} \quad m<_{1}
$$

で表される。この事は $\tan \delta$ は $f$ に無關係でなく其の值は $f$ の增加と共に減少する事を示してるる。

$$
W=k f^{m}=V^{2} 2 \pi f C \tan \delta
$$

$$
\therefore \quad C \tan \delta=k f^{m} / V^{2} 2 \pi f=k / V^{2} 2 \pi f^{(1-m)}
$$

若しCの周波數による變化が省略的であるならば

$$
\tan \delta=k / V^{2} 2 \pi C f^{(1-m)}
$$

饮 $f$ の增加と共に $\tan \delta$ は減少する事を示す。湘定の結果も亦一般に $f$ の墂加と共に $\tan \delta$ の減少する事を示 してるる。然し無線周波數の蛞き高周波數の場合はこれと著しく晎り上式を以て表す事は出來ない。若し上式 か高周波數の場合にも適用出來るならば tan

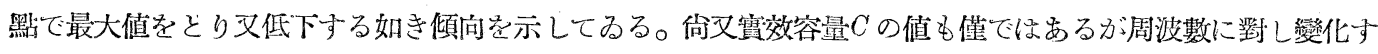
る事も示されてるる。

(2) 溫度の影響

一般に使用される誘電體の中であるものは溫度の上昇と共に損失も急激に霄大する事は總ての研究者の一致

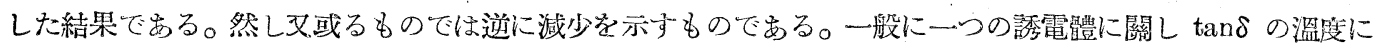
よる變化に就いての測定結果を見るに符三圖に示す樣な曲線となる。

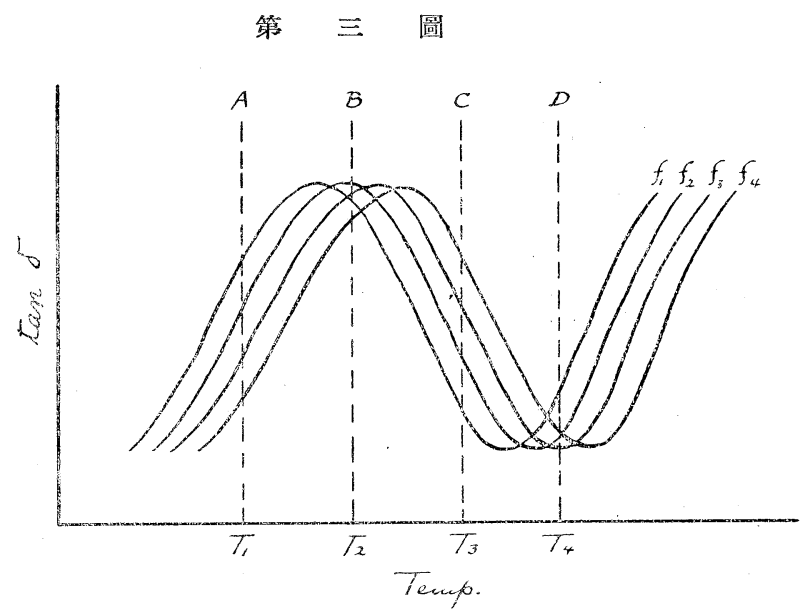

圖の $f_{1} f_{2} \cdots$ は何れも黑当孔る周波數である。この圖に見る樣に $\tan \delta$ と溫度との關係曲線には最高點と最 低點が存在する。而子其の位置の溫度は周波數によつて異る。この結果からワグナーは次の樣に謂つてるる。 $\tan \delta$ を種々なる楇波數に於て溫底の函數で表す時は或る一定の誘電蹬に於ては各周波數に於ける $\tan \delta$ 一溫 度曲線は一定の形を持つてるる。唯 $f_{1}$ の場合と $f_{2}$ の場合に於てはこれを一つの圖紙に作圖する時曲線が多少 ずれるだけである。若し斯くの如きものとすれば㓈電䀎損失はその測定溫度の範園により或るものに於ては溫 度の上昇と共に堶加し叉或るものは区對に減少する事も考へられる。更に種々なる誘電體に於て若し常溫が第 
三圖に於ける $T_{1}, T_{2}, T_{3}, T_{4}$ の溫度に相當するものとす扎ば其等誘電體の常溫に於ける $\tan \delta$ ととの關係 は夫々第四圖の $A, B, C, D$ の如き曲線になる重も考へられる。

第四圆

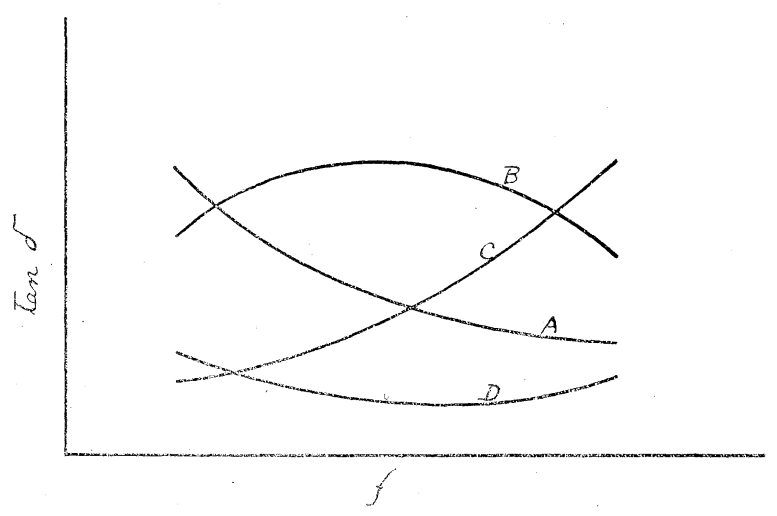

少一般に固體の誘電體に於て溫度を上昇せしめて熔融點以上に達せしめる時は損失は急激に堌大寸るるので ある。

(3) 電暍の影響

前述の樣に誘電鳢損失は

$$
W=V^{2} \omega C \tan \delta
$$

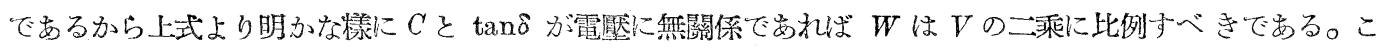

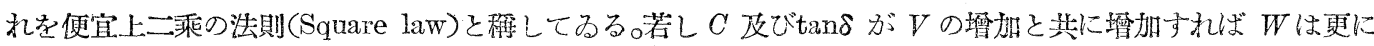

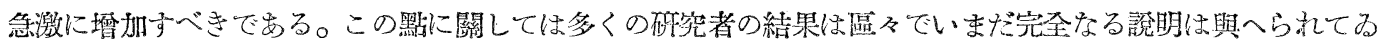
ない。或る研究者は他の條件が一定であれば艺光放電が生ずる電厴迄は Wは二乘の法則に從ふと謂つてるる。

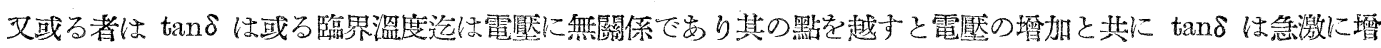
加する。又長時間高電壓を印加すれば溫度上昇の鷽に $W$ は壻加し $\tan \delta$ の增加は屡これに起因するといつて

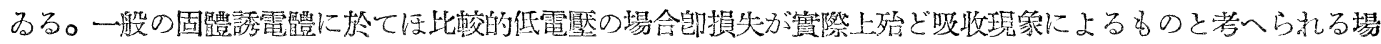
合は損失は電壓の二乘に比例するが更に電壓が上昇してイオン化又は艺光放電の如きものが起り得る樣にな机 ば損失は電壓と共に急激に墰すものと考へられる。

(4) 大氣の濕度の影響

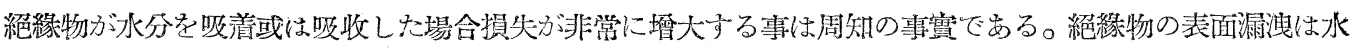

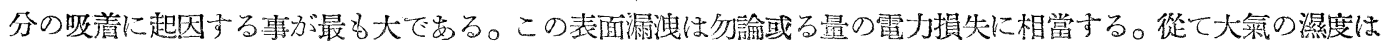
謤電體の使用上央大なる影響を持つのである。

\section{v. 誘電體の力率及び誘電率}

一般に電氣絕緣物として使用される誘電觶の力䒺及誘電率は次表の如きものである。 （誘電紊の値は一般的な值でする） 


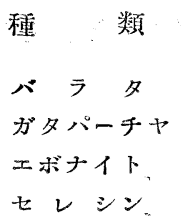

\section{測定周波數} (サイクル)

800

800

$500 \sim 5,000$

500

1,000

5,000

50

1,000

5,000

50,000

140,000

$10^{5} \sim 10^{6}$

50

50

1,000

$5 \times 10^{5}$

500

5,000

500

1,000

5,000

$-500$

1,000

5,000

800

50

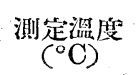

20

II

II

II

. II

"I

II

II

II

\section{II}

\section{"I}

"I

"

I)

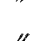

"I

"I

\section{"}

"I

II

"I

II

II

II

II

"I

"
$10^{4} \tan \delta$

$\begin{array}{rr}50 & 2.6 \sim 3.5 \\ 100 \sim 300 & 2.6 \sim 3.5 \\ 25 \sim 230 . & 2.5 \\ 0.2 & 2.1 \\ 0.3 & \\ 0.5 & \\ 40 & 6 \sim 9\end{array}$

30

15

8

4

$4 \sim 75$

500

$3 \sim 15$

$2 \sim 10$

2

115

90

170

150

110

0.5

0.8

1.2

$120 \sim 160$

$50 \sim 200$
$5 \sim 7$

$4 \sim 6.8$

$4.5 \sim 9$

$2.3 \sim 3$

$1.8 \sim 2.3$

講

演

\section{コットレル丽氮收塵法と其の應用（其二）}

志 賀

潔

\section{(IV) 窒栄方面に對するコットレル法の應用}

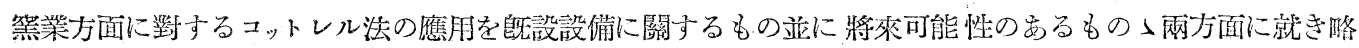
述する事とする。

(1) セメント製造工篻方面

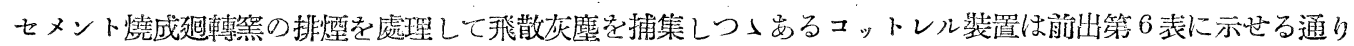

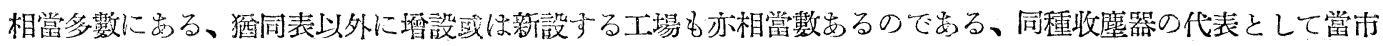

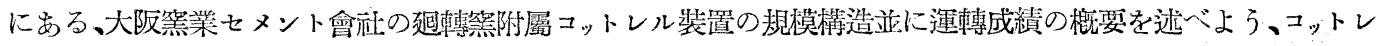

